\title{
Pemberdayaan Pertanian Terpadu Bermodal Limbah Ladang, Dapur, dan Kandang Berbasis Koperasi di Desa Cibitung Tengah, Bogor
}

\section{(Empowerment of Integrated Farming from Farm, Household, and Livestock Wastes Based on Community Cooperarive Funding in Cibitung Tengah, Bogor)}

\author{
Dimas Andrianto 12*, Husnawati ${ }^{3}$, Zulfikar Muchammad ${ }^{3}$, Danty Oktiana Prastiwi ${ }^{3}$, Muhammad Farhan ${ }^{3}$, \\ Imelia Dewi ${ }^{3}$, Gina Oktaviani Sabrina ${ }^{3}$, Elgiani Yassifa Yulia Nur Insari ${ }^{3}$, Amrista Fanzani Kananga ${ }^{3}$, \\ Slamet Hamzah ${ }^{3}$, Sri Wahyuni ${ }^{3}$, Muhammad Irfansyah Pradika ${ }^{3}$ \\ 1 Departemen Biokimia, Fakultas Matematika dan Ilmu Pengetahuan Alam, Institut Pertanian Bogor, \\ Kampus IPB Dramaga, Bogor 16680. \\ 2 Pusat Kajian Sains Halal, Institut Pertanian Bogor, Kampus IPB Baranang Siang, Bogor 16129. \\ 3 Mahasiswa Program Studi Sarjana Biokimia, Fakultas Matematika dan Ilmu Pengetahuan Alam, Institut Pertanian Bogor, \\ Kampus IPB Dramaga, Bogor 16680. \\ *Penulis Korespondensi: dimasandrianto@apps.ipb.ac.id \\ Diterima Januari 2020/Disetujui September 2020
}

\begin{abstract}
ABSTRAK
Kegiatan pertanian di Desa Cibitung Tengah, Kecamatan Tenjolaya, Kabupaten Bogor, Jawa Barat meliputi pertanian sayuran dan peternakan domba. Beberapa permasalahan pada masyarakat Cibitung Tengah adalah penggunaan pupuk didominasi pupuk kimiawi, masyarakat belum mampu mengelola limbah pertanian dan domestik dengan baik bahkan sebagian dibuang ke sungai, serta kelembagaan Gabungan Kelompok Tani (Gapoktan) dan Kelompok Wanita Tani (KWT) belum berfungsi optimal. Penggunaan sistem pertanian terpadu dapat meningkatkan produktivitas lahan dan ternak sekaligus mengurangi volume limbah pertanian dan rumah tangga. Kegiatan pemberdayaan kepada masyarakat ini bertujuan untuk meningkatkan pengetahuan dan keterampilan masyarakat di Desa Cibitung Tengah terkait pengolahan limbah pertanian dan domestik sehingga dapat mengatasi permasalahan sampah dan penggunaan pupuk kimiawi berlebihan. Pelaksanaan diskusi dan sosialisasi dilakukan dengan pendekatan rumah ke rumah terutama untuk masyarakat yang belum tergabung aktif di Gapoktan dan KWT. Kegiatan yang telah dilaksanakan berupa edukasi seperti penyuluhan sistem pengolahan sampah pada masyarakat, pelatihan pengolahan sampah organik atau Black Soldier Fly (BSF) training, pengolahan sampah organik dengan teknologi BSF, pembuatan silase sebagai pakan kambing, dan pembuatan brand hasil pertanian. Program pemberdayaan ini juga menghasilkan produk baru atau produk olahan yang dapat menambah pendapatan bagi masyarakat Cibitung Tengah seperti hasil dari pengolahan maggot, produk CT-Fresh, keuntungan hasil dari bank sampah, dan hasil kerajinan dari sampah.
\end{abstract}

Kata kunci: bank sampah, caisim, cibitung tengah, maggot, silase

\begin{abstract}
Farming in Cibitung Tengah Village, Tenjolaya Subdistrict, Bogor District, West Jawa is characterized by vegetables and sheep farming. Several problems in farming are the use of chemical fertilizers, management of agriculture and domestic wastes properly; even some people disposing of garbage in the river and also, the institutional Farmer Group Association (Gapoktan) and Female Farmer Group (KWT) are not functioning optimally. The use of an integrated farming system can increase land and livestock productivities and reduce the volume of agriculture and domestic wastes all at once. This community empowerment activity aimed to increase the people's knowledge and skill of Cibitung Tengah Village in terms of processing agricultural and domestic wastes. Thus it will overcome the garbage and overuse of chemical fertilizer problems. The discussions and outreach activities were done by a door-to-door approach, especially for people who have not been actively involved in Gapoktan and KWT. This research was carried out with several educational activities such as counseling on community waste management systems, training on organic waste processing, Black Soldier Fly (BSF) training, processing organic waste with BSF technology, making silage as goat feed, and making branding of agricultural products. This empowerment program produced new products or processed products. The products will increase the income for the people of Cibitung Tengah, such as maggot processing products, CSFresh products, results from waste banks, and handicraft products from waste.
\end{abstract}




\section{PENDAHULUAN}

Desa Cibitung Tengah berada di Kecamatan Tenjolaya, Kabupaten Bogor. Desa dengan total penduduk lebih dari 10.644 jiwa (2016) ini, mencakup area seluas 310,8 ha. Area tersebut mencakup pemukiman seluas 68,50 ha, sawah seluas 65,24 ha, area ladang seluas 99,70 ha dan perkebunan seluas 68,55 ha. Masyarakat desa ini berprofesi sebagai petani, buruh tani, peternak, pedagang, dan sebagian kecil PNS. Data komoditas unggulan yang ada di Cibitung Tengah pada tahun 2014-2016 di antaranya adalah padi dengan total luas 45,23 ha, palawija dengan total luas 28,24 ha, dan caisim dengan total luas 3,45 ha. Peternakan merupakan sektor lain yang banyak dikelola masyarakat dalam skala rumah tangga, namun kuantitasnya sulit diperkirakan karena bersifat temporer akibat terkendala ketersediaan pakan yang fluktuatif.

Desa Cibitung Tengah mempunyai beberapa masalah terkait dengan pengolahan limbah dan sosial ekonomi masyarakat. Masalah pengolahan limbah adalah tingginya limbah caisim, limbah dapur, kotoran ternak yang belum diolah, kebiasaan membuang sampah di sungai masih tinggi serta pemanfaatan limbah pertanian dan peternakan belum optimal. Permasalahan sosial ekonomi meliputi ibu rumah tangga masih banyak yang menganggur, kebiasaan berkoperasi rendah serta biaya untuk pupuk dan pakan ternak mahal. Selain itu peran Gabungan Kelompok Tani (Gapoktan) dan Kelompok Wanita Tani (KWT) belum maksimal. Pemetaan masalah tersebut kami lakukan berdasarkan observasi lapang pada tahun 2017.

Meskipun demikian terdapat beberapa potensi desa yang dapat dimanfaatkan. Pertama, potensi menjadi lumbung pangan beras, sayuran dan peternakan kambing. Kedua, setiap petak lahan caisim per harinya menghasilkan $50 \mathrm{~kg}$ limbah yang belum dimanfaatkan secara optimal. Ketiga, keberadaan pertanian dan peternakan berpotensi untuk disinergikan. Keempat, keberadaan Gapoktan dan KWT sangat membantu proses sosialisasi dan diskusi terkait pemetaan masalah yang dilakukan oleh tim peneliti. Oleh sebab itu, program pemberdayaan dilaksanakan sebagai gerakan pertanian terpadu bermodal limbah ladang, dapur, dan kandang berbasis koperasi dalam mewujudkan desa lumbung pangan di Desa Cibitung Tengah, Kabupaten Bogor. Lumbung pangan ini diperlukan untuk mencapai tujuan nasional Indonesia emas 2045 dan mewujudkan poin Zero Hunger dari SDGs
2030 (Elsa 2012).

Kegiatan ini menghasilkan rancangan manajeman pemberdayaan sesuai kearifan lokal. Kegiatan pemberdayaan ini bertujuan untuk meningkatkan pengetahuan dan keterampilan masyarakat di Desa Cibitung Tengah terkait pengolahan limbah pertanian dan domestik sehingga dapat mengatasi permasalahan sampah dan penggunaan pupuk kimiawi berlebihan. Manfaat pemberdayaan masyarakat ini adalah agar masyarakat mendapatkan pengetahuan dan teknologi pengelolaan limbah yang menghasilkan produk bernilai ekonomi, keterpaduan pertanian-peternakan, menurunkan biaya produksi, dan meningkatkan pendapatan. Secara kelembagaan, masyarakat memperoleh wadah berorganisasi dengan keuntungan ekonomi dan sosial tanpa mengabaikan kearifan lokal.

\section{METODE PELAKSANAAN KEGIATAN}

\section{Tempat dan Waktu}

Program pemberdayaan pertanian terpadu kepada warga Desa Cibitung Tengah dirintis pada tahun 2017 setelah resmi menjadi desa binaan himpunan mahasiswa Biokimia IPB (CREBs). Program ini dijalankan pada bulan AprilDesember 2018. Desa Cibitung Tengah berada di Kecamatan Tenjolaya, Kabupaten Bogor Jawa Barat. Desa Cibitung ini memiliki 5 RW dan 26 RT. Secara umum keadaan geografis Desa Cibitung Tengah berada di lereng sebelah Utara Gunung Salak dengan ketinggian $1350 \mathrm{mdpl}$. Suhu ratarata $27,5^{\circ} \mathrm{C}$. Desa ini dibatasi oleh Sungai Cinangneng di sebelah Timur, yang menjadi perbatasan dengan Desa Situdaun, di sebelah Barat dibatasi oleh Sungai Ciampea yang sekaligus menjadi batas antara Desa Cibitung Tengah dengan Desa Ciampea Udik, Kecamatan Ciampea (Gambar 1).

\section{Tahapan dan Metode Pelaksanaan}

Pemberdayaan pertanian terpadu mengintegrasikan pertanian, peternakan, pengelolaan limbah, dan pemberdayaan koperasi. Kegiatan yang dilakukan meliputi kajian lapang, diskusi/ ngariung bersama warga, studi banding dengan mengundang Gapoktan Cikarawang, pelatihan pembuatan silase, serta sistem pengolahan sampah organik dan anorganik di Cibitung Tengah. Metode pelaksanaan dikemas dalam beberapa kegiatan, yaitu penyuluhan sistem pengolahan sampah masyarakat, pelatihan 


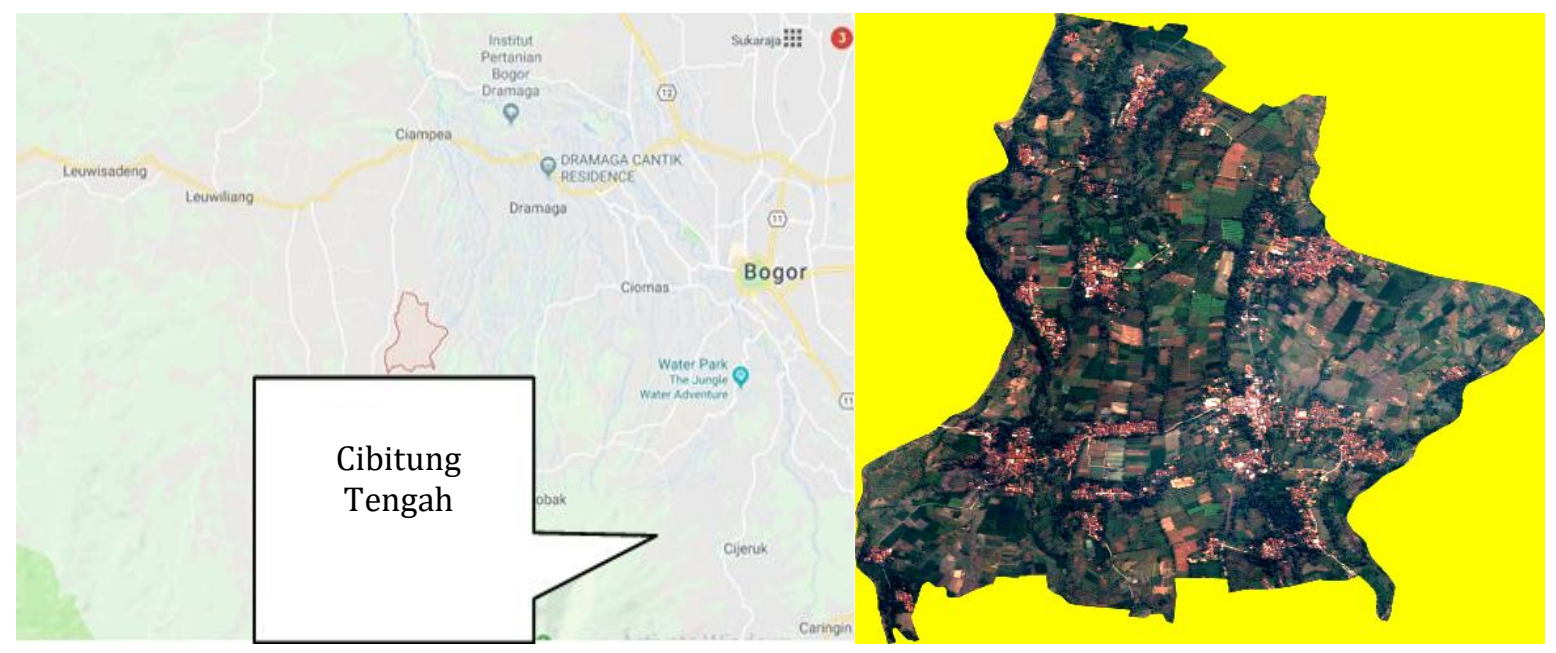

Gambar 1 Desa Cibitung Tengah.

pengolahan sampah organik menggunakan Black Soldier Fly (BSF), pembuatan silase sebagai pakan kambing, dan pembuatan brand hasil pertanian.

Metode yang disusun merupakan hasil diskusi dan analisis antara masyarakat, mahasiswa, dan mitra untuk menyelesaikan masalah berdasarkan potensi yang ada. Pengelolaan sampah terintegrasi ini dilakukan dalam basis koperasi desa. Koperasi dipilih karena sesuai dengan kearifan lokal masyarakat setempat dan merupakan wujud konkret dari partisipasi masyarakat yang berkelanjutan.

\section{- Diskusi bersama warga desa}

Diskusi dilakukan antara warga, mahasiswa maupun mitra yang bekerja sama selama pemberdayaan di Desa Cibitung Tengah. Diskusi ini bertujuan untuk membahas masalah-masalah yang ada, merumuskan program yang akan dilakukan, penyusunan koordinator dari pihak masyarakat, mengembangkan potensi desa yang dapat dimaksimalkan, membahas perkembangan, dan melakukan evaluasi terhadap program. Diskusi dilakukan setiap kamis malam.

\section{- Penyuluhan sistem pengolahan sampah pada masyarakat}

Sistem pengolahan sampah diintegrasikan dengan pemanfaatan limbah dikaitkan dengan kesehatan. Selain untuk mewujudkan ketahanan pangan, sistem ini dilakukan dengan memberikan edukasi pemilahan sampah dengan menyisipkan aspek ekonomi. Pemeriksaan kesehatan yang akan diselenggarakan menggunakan biaya dari sampah anorganik yang terpilah. Pemeriksaan meliputi uji urine, pengukuran tekanan darah, bobot badan dan tinggi badan, uji golongan darah, gula darah, dan beberapa uji kesehatan lain yang akan dilaksanakan oleh mahasiswa biokimia IPB. Selain itu dilakukan juga konsultasi kesehatan, dan pemeriksaan dari dokter secara langsung.

Program ini juga membuat tanaman apotik hidup yang digunakan untuk obat masyarakat secara herbal. Masyarakat hanya perlu memberikan 5 botol plastik yang sudah dilepas kemasannya dan dipisahkan tutup botolnya atau 5 kardus atau 5 gelas plastik yang sudah dibersihkan dari kemasannya agar mendapatkan layanan klinik sampah tersebut. Luaran dari program ini adalah edukasi tentang pemilahan sampah, tanaman apotik hidup, pola hidup sehat, dan obat herbal.

\section{- Pelatihan pengolahan sampah organik}

Pelatihan yang diberikan berupa pengenalan sistem pengolahan sampah organik dan sampah nonorganik (Gambar 2). Fokus pelatihan ini terdiri atas dua komponen. Komponen pertama adalah pengolahan sampah organik dengan teknologi BSF dan teknologi silase. Komponen kedua adalah pengolahan sampah anorganik dengan sistem bank sampah dan pembangunan TPS.

Tujuan dari program ini adalah untuk menciptakan budaya yang peduli akan sampah, terutama sampah anorganik dan peduli untuk membedakan jenis sampah anorganik, sehingga sampah anorganik dapat diolah kembali atau dimanfaatkan untuk menjadi barang yang bernilai jual sehingga meningkatkan ekonomi masyarakat Cibitung Tengah. Pengolahan ini bermitra dengan Pos Pandai Rangga Mekar. Kemitraan ini berguna membantu masyarakat untuk membuat bank sampah dari pengenalan jenis sampah, membuat sistem bank sampah, 


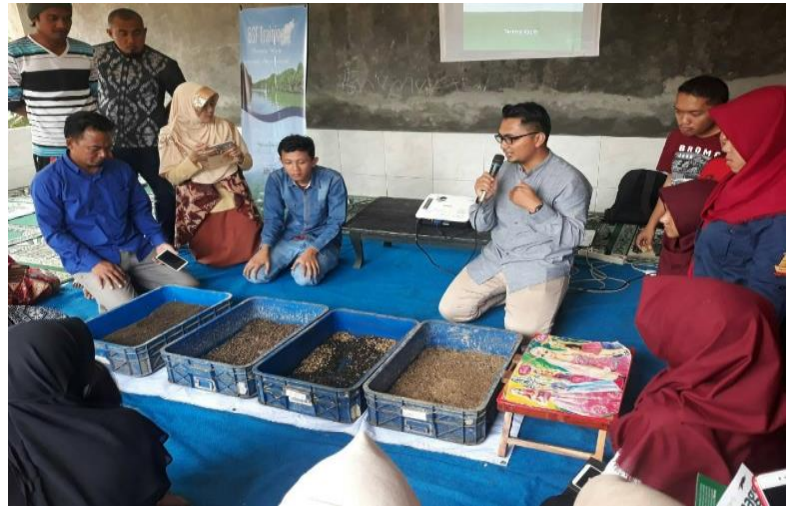

Gambar 2 Pelatihan black soldier fly dan pengolahan maggot.

mengajarkan pengolahan sampah menjadi kerajinan tangan, dan membantu menciptakan budaya peduli sampah.

Pengelolaan sampah dilakukan dengan membangun tempat pembuangan sampah sementara (TPS) dengan pemilahan sampahnya (organik, plastik, kaca, kardus, dan kertas). Hal ini dilakukan karena Desa Cibitung Tengah hanya memiliki 3 TPS untuk satu desa. Sementara kapasitasnya kurang bisa menampung jumlah sampah yang dihasilkan warga. Pembuatan TPS baru diharapkan mencegah warga membuang sampah di sungai atau di tanah kosong. Selain pembangunan TPS, juga dilakukan edukasi mengenai pemilahan dan pembentukan sistem TPS yang berkelanjutan hingga ke bank sampah agar dimanfaatkan menjadi produk yang bernilai ekonomi.

\section{- Studi banding}

Studi banding merupakan edukasi program pelatihan BSF dan penggunaan teknologi silase. Pada tahun 2018 masyarakat Cibitung Tengah bersama mahasiswa CREBs IPB melakukan studi banding ke Gapoktan Cikarawang untuk belajar sistem dan administrasi Gapoktan dan belajar mengenai pembuatan silase (teknologi pakan ruminansia). Selanjutnya, masyarakat Cibitung Tengah bersama civitas Departemen Biokimia IPB melakukan studi banding ke Pos Pandai Rangga Mekar di Dredet Bogor. Masyarakat belajar langsung mengenai TPS, sistem bank sampah, administrasi bank sampah, dan pengelolaan sampah serta belajar kerajinan dari sampah.

\section{- Pengolahan sampah organik dengan teknologi black soldier fly}

Sampah organik yang berasal dari limbah ladang dan dapur dikonversi menggunakan larva Black Soldier Fly (BSF), Hermetia illucens L. dalam bentuk prepupa. Teknologi ini berpotensi untuk memberikan nilai tambah pada sampah. $H$. illucens tersebar luas di wilayah tropis. Fase hidupnya meliputi telur, mini larva, prepupa, pupa, dan lalat hitam atau BSF. Pada fase larva dan prepupa, $H$. illucens mengumpulkan banyak energi melalui pemecahan bahan organik dari sampah. Fase tersebut dilalui dalam waktu sekitar 1 bulan.

Morfologi pada prepupa memiliki panjang sekitar 2-3 cm, berwarna putih, dan menyukai kondisi gelap. Pada fase ini penguraian sampah dilakukan. Pada fase pupa, tubuh $H$. illucens mengeras dan berubah warna menjadi hitam. Beberapa hari kemudian BSF kecil akan keluar dari pupa dan hidup sekitar 2 minggu. Pada masa ini, BSF tidak membutuhkan asupan nutrisi kecuali air. Energi diperoleh selama masa prepupa dan larva. Produk dari sistem BSF berupa pupuk kompos hasil degradasi sampah organik serta larva $H$. illucens itu sendiri atau sering disebut maggot. Pupuk kompos ini nantinya dapat digunakan untuk memupuk caisim warga Desa Cibitung Tengah. Pupuk kompos ini tergolong pupuk organik yang dapat mempertahankan dan meningkatkan hasil tanaman (Inrianti et al. 2019).

\section{- Pembuatan silase sebagai pakan kambing}

Silase merupakan pakan ternak yang telah diawetkan, diproduksi atau dibuat dari tanaman atau limbah industri pertanian yang dicacah dengan kandungan air rendah melalui proses ensilasi. Proses ensilasi merupakan proses pengantar, menggunakan bakteri asam laktat, dan terjadi dalam kondisi anaerob. Silase yang terbentuk sebagai akibat fermentasi asam laktat dapat disimpan dalam waktu yang lama. Silase dapat digunakan sebagai pakan alternatif pada musim kering ketika hijauan sulit diperoleh. Penambahan bakteri asam laktat dan enzim pendegradasi sel pada rumput leguminosa dapat meningkatkan kecernaan dan kelarutan nitrogen, sehingga inokulasi bakteri asam laktat pada silase akan mempercepat proses fermentasi (Harrison et al. 1994).

Silase dibuat dari limbah pertanian warga, kemudian dijadikan sebagai pakan kambing. Silase dari berbagai hijauan sangat cocok diterapkan karena Cibitung Tengah memiliki beragam tumbuhan, khususnya tumbuhan hijau yang dapat dijadikan sebagai pakan. Selain itu, banyak warga yang memiliki hewan ternak ruminansia atau kambing sehingga teknologi ini dapat membantu mengurangi biaya produksi 
peternakan. Pemberian silase dilakukan kepada 6 ekor kambing jantan. Kambing tersebut diberi pakan silase selama 3 bulan yang hasilnya dikelola dengan sistem paro. Hal ini bertujuan untuk membiasakan warga terhadap pakan silase dan agar warga melihat langsung hasil ternak yang diberi pakan silase serta menghitung dampak ekonominya.

\section{- Pembuatan brand hasil pertanian}

Hasil pertanian warga Desa Cibitung Tengah ditingkatkan nilai jualnya melalui branding product. Program ini berisi edukasi warga dalam cara mengemas caisim agar dapat dijual ke supermarket serta cara menyortir caisim menjadi grade A, B, dan C. Caisim juga diolah menjadi kripik caisim. Program ini membuat brand hasil pertanian masyarakat, yaitu CS Fresh. Hasil awal dari pengolahan tersebut dijual ke pameran pasar rakyat tani di IPB dan di Balaikota Bogor.

Metode Pengumpulan, Pengolahan, dan Analisis, Data

Metode pengumpulan data kualitatif dilakukan dengan wawancara dengan stakeholder dan tokoh masyarakat, pengamatan langsung di lapangan, dan diskusi dengan masyarakat Desa Cibitung Tengah, Kecamatan Tenjolaya, Kabupaten Bogor, Jawa Barat. Pengumpulan data kuantitatif pengomposan diperoleh dari simulasi pengomposan konvensional dan pengomposan dengan menggunakan maggot pada lahan masyarakat. Data kuantitatif harga sampah mengacu pada data harga sampah di pengepul sampah pada tahun 2018, sedangkan data harga caisim, produk olahannya, dan maggot mengacu pada harga jual selama kegiatan.

Pengolahan data kualitatif dilakukan secara deskriptif, sedangkan data kuantitatif disajikan dalam bentuk tabel. Analisis deskriptif digunakan untuk membahas berdasarkan logika ilmiah. Analisis SWOT bertujuan merangkum hasil pengamatan dalam bentuk matriks SWOT sebagai rekomendasi strategi pengelolaan sampah dan limbah pada Desa Cibitung Tengah. Analisis SWOT disusun menurut metode Dian \& Ira (2016).

\section{HASIL DAN PEMBAHASAN}

\section{Kondisi Umum Pelaksanaan Kegiatan}

Masyarakat Cibitung Tengah sebelum pelaksanaan kegiatan memiliki beberapa permasa- lahan. Pertama, belum mampu mengelola limbah pertanian dengan baik. Kedua, penggunaan pupuk didominasi pupuk kimiawi yang mahal. Ketiga, kebiasaan membuang sampah di sungai masih tinggi. Keempat, pemilahan sampah dapur rendah. Permasalahan terakhir adalah kelembagaan Gapoktan dan KWT belum berfungsi optimal. Kehidupan sosial masyarakat desa Cibitung Tengah sarat akan kearifan lokal. Kegiatan yang rutin dilakukan masyarakat adalah berladang di pagi hingga sore serta pengajian setelah maghrib pada hari kamis malam. Pelaksanaan diskusi dan sosialisasi yang sebelumnya dilakukan memerlukan pendekatan pintu ke pintu terutama untuk masyarakat yang belum tergabung aktif di Gapoktan dan KWT, Gambar 3 menunjukkan sosialisasi program di Desa Cibitung Tengah.

\section{Pupuk Kompos dari Black Soldier Fly}

Proses pengolahan sampah organik menghasilkan pupuk kompos dan maggot yang dapat menjadi pakan ternak unggas dan ikan. Maggot memiliki kandungan $45 \%$ protein dan 30\% lemak. Proses degradasi sampah dengan menggunakan bantuan maggot dapat menjadi salah satu alternatif yang menjanjikan dalam pengelolaan sampah. Enzim yang terkandung dalam larva BSF terbukti dapat mereduksi zat kontaminan dari sampah. Larva BSF dapat mengonsumsi serta mendegradasi bahan organik yang terkandung dalam limbah hingga sebesar $70 \%$, sehingga penerapan teknologi BSF dapat mendegradasi sampah secara efektif dan menjadi pakan alternatif ternak di Desa Cibitung Tengah.

Program ini dilakukan dengan melibatkan perusahaan budi daya maggot, yaitu PT Biomagg Indonesia sebagai mitra. Edukasi Maggot BSF terhadap warga Cibitung Tengah dilakukan untuk dapat memberikan manfaat kepada masyarakat. Kerja sama juga dilakukan dengan

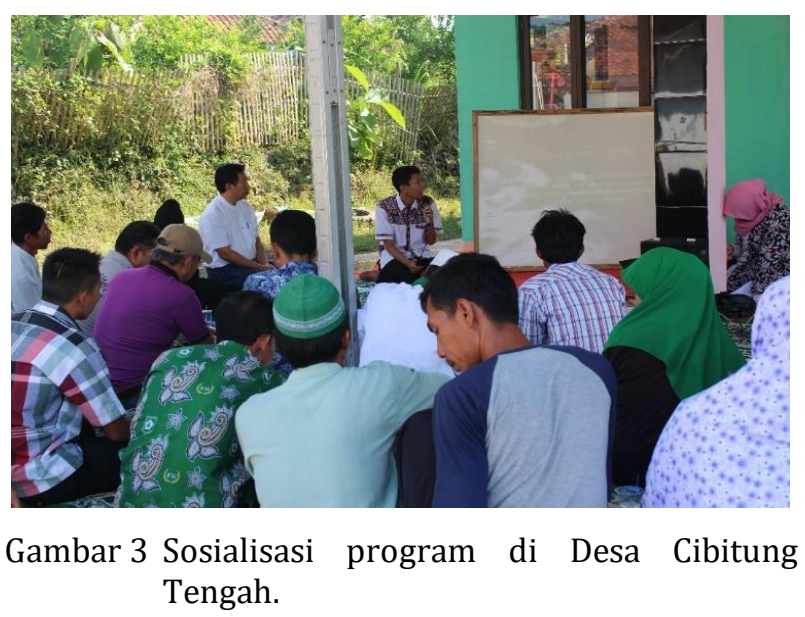


Dinas Ketahanan Pangan, Kecamatan Tenjolaya dan Komunitas Penggerak Ekonomi Rakyat (KOPER) untuk membuat instalasi maggot BSF dan merealisasikan sistem pengolahan sampah menggunakan Maggot BSF. Instalasi pengolahan sampah menggunakan maggot BSF didirikan berdasarkan hasil studi banding ke PT Biomagg Indonesia.

\section{Analisis Maggot Black Soldier Fly untuk Integrasi Pertanian dan Peternakan}

Maggot BSF dapat mendegradasi sampah organik, kotoran hewan, dan sisa hasil pertanian. Hasil pendegradasian maggot BSF, yaitu maggot untuk pakan ternak dan menjadi pupuk kompos untuk mempercepat pertumbuhan dari tanaman. Tabel 1 menunjukkan bahwa kandungan protein pada larva cukup tinggi, sebesar $44,26 \%$ dengan kandungan lemak sebesar 29,65\% (Wardhana 2016).

Nilai asam amino, asam lemak, dan mineral yang terkandung di dalam larva tidak kalah dengan sumber-sumber protein lainnya, sehingga larva BSF merupakan bahan baku ideal yang dapat digunakan sebagai pakan ternak. Maggot BSF juga berfungsi sebagai tepung ikan yang menjadi bahan utama pembuatan pakan ikan ataupun pakan ayam dan bebek. Tepung maggot BSF juga dapat menjadi campuran atau konsentrat pada pakan ruminansia. Tepung larva BSF cukup sesuai sebagai bahan pakan karena mengandung asam amino, lemak, dan kalsium yang dibutuhkan untuk pertumbuhan ruminansia, meskipun kandungan abunya relatif tinggi (Diener et al. 2011). Berdasarkan hasil uji palatabilitas, ternak ruminansia lebih suka pakan yang mengandung larva BSF daripada pakan berbasis tepung kedelai sebagai sumber protein.

Hasil pendegradasian sampah dari maggot berupa pupuk kompos. Pupuk kompos yang dihasilkan mempunyai kelebihan, yaitu kadar air yang rendah, kaya nitrogen, dan kaya unsur organik lainnya. Waktu pengomposan selama 4 minggu, jauh lebih cepat daripada pengomposan konvensional selama 14 minggu (Paz et al. 2015). Selain pupuk terdapat biogas dalam pendegradasian sampah menggunakan maggot, namun belum dimanfaatkan pada kegiatan ini.

Sisi ekonomi, maggot BSF ini mempunyai nilai ekonomis yang tinggi dibanding pupuk konvensional. Maggot BSF memiliki harga yang lebih rendah dari tepung ikan sehingga dapat menjadi alternatif untuk pakan ternak yang mengakibatkan cost production berkurang. Hal ini tentu berfungsi meningkatkan hasil penjualan ternak. Perbandingan pengomposan konvensional dengan maggot terlihat pada Tabel 2.

\section{Analisis Ekonomi Bank Sampah dan Produk Hasil Pertanian}

Program bank sampah bertujuan untuk mengurangi dan mengolah sampah, serta membantu masyarakat untuk meningkatkan kesadaran akan pentingnya pengolahan sampah. Program ini memiliki kelebihan dari segi ekonomi yang berperan menambah nilai ekonomi bagi warga desa dengan menggunakan sistem bank sampah. Sistem bank sampah memanfaatkan sampah-

Tabel 1 Persentase kandungan nutrisi larva BSF (Wardhana 2016)

\begin{tabular}{lclrlclc}
\hline Proksimat & Kadar (\%) & Asam Amino & Kadar (\%) & Asam Lemak & Kadar (\%) & Mineral & Kadar (\%) \\
\hline Air & 2,38 & Serin & 6,35 & Linoleat & 0,70 & $\mathrm{Mn}$ & $0,05 \mathrm{mg} / \mathrm{g}$ \\
Protein & 44,6 & Glisin & 3,80 & Linolenat & 2,24 & $\mathrm{Zn}$ & 0,09 \\
Lemak & 29,65 & Histidin & 3,37 & Jenuh & 24,00 & $\mathrm{Fe}$ & 0,68 \\
& & & & $\mathrm{mg} / \mathrm{g}$ & & \\
& & Arginin & 12,95 & Monomer & 8,71 & $\mathrm{Cu}$ & 0,01 \\
& & Treonin & 3,16 & & & $\mathrm{P}$ & 0,13 \\
& & Alanin & 25,68 & & $\mathrm{Ca}$ & 55,65 \\
& & Prolin & 16,94 & & $\mathrm{Mg}$ & 3,50 \\
& & Tirosin & 4,15 & & & $\mathrm{Na}$ & 13,71 \\
& & Valin & 3,87 & & & \\
& Sistin & 2,05 & & & & \\
& & Isoleusin & 5,42 & & & & \\
& Leusin & 4,76 & & & & \\
& Lisin & 10,65 & & & & \\
& Taurin & 17,53 & & & & \\
& Sistein & 2,05 & & & & \\
& NH & & & & & \\
& Ornitin & 4,33 & & & & \\
& & 0,51 & & & & \\
\end{tabular}


Tabel 2 Perbandingan pengomposan konvensional dengan Maggot

\begin{tabular}{|c|c|c|}
\hline Variabel & $\begin{array}{c}\text { Pengomposan } \\
\text { konvesional }\end{array}$ & Maggot \\
\hline Input sampah & $100 \mathrm{~kg}$ & $100 \mathrm{~kg}$ \\
\hline Lama waktu & 14 minggu & 4 minggu \\
\hline Hasil & - 40 kg kompos & $\begin{array}{l}10 \text { kg maggot } \\
30 \text { kg kompos }\end{array}$ \\
\hline $\begin{array}{l}\text { Valuasi nilai } \\
\text { Ekonomi }\end{array}$ & -0 & 50000 \\
\hline & 20000 & 15000 \\
\hline Total (Rp) & 20000 & 65000 \\
\hline Perbandingan nilai & 1 & 3,25 \\
\hline
\end{tabular}

sampah yang ada di sekitar desa yang kemudian dipisahkan antara sampah organik dengan nonorganik.

Sampah organik akan diolah dengan penambahan maggot untuk dijadikan pakan ternak dan pupuk kompos yang dapat digunakan serta dijual oleh warga desa. Sampah nonorganik memiliki sistem jual-beli yang melibatkan civitas Departemen Biokimia IPB sebagai perantara antara warga yang mengumpulkan sampah non-organik dengan para pengepul sampah di sekitar desa. Sistem jual beli sampah non organik bertujuan untuk membuat warga desa terbiasa dengan pemilahan dan pengolahan sampah non-organik sebelum dijual sehingga harga yang ditawarkan juga berbeda. Cara tersebut dinilai sangat efektif untuk menambah pemasukan warga dan mengurangi sampah di desa Cibitung Tengah. Tabel 3 merupakan harga dari penjualan di bank sampah desa Cibitung Tengah:

Bank sampah menanamkan kebiasaan suka menabung pada warga walaupun menabung dalam bentuk sampah. Bank sampah membantu menambah pendapatan keluarga yang bisa dimanfaatkan untuk membiayai anak sekolah, membeli seragam dan sebagainya. Selain itu, adanya bank sampah dapat membantu ibu rumah tangga menghasilkan uang dengan cara memberikan kegiatan berupa pembuatan kerajinan sampah yang nantinya akan dijual, sehingga mereka memiliki penghasilan sendiri. Hasil kerajinan dari bank sampah dapat menghasilkan tas, tikar, dan pernak pernik lainnya dengan harga jualnya Rp 5.000-40.000. Bank sampah yang dilaksanakan dengan rutin akan membantu meningkatkan perekonomian warga secara konsisten dan secara tidak langsung membentuk karakter warga desa yang mandiri. Bank sampah ini juga mengurus pengelolaan sampah organik, yaitu pengolahan menggunakan maggot yang dinilai cukup efektif untuk pengolahan hasil limbah pertanian warga desa yang biasanya tidak diperhatikan.

Selain bank sampah, hal yang menjadi pemasukan tambahan dari warga adalah dari membuat brand lokal pertanian. Pembuatan brand ini bertujuan untuk membantu warga membuat produk baru hasil pertaniannya, membantu pengemasan produk hasil pertanian, membuat brand dari hasil pertanian warga dan mencari pasar penjualan baru (Gambar 4). Branding akan menuntun warga agar membuat sistem koperasi dari hasil pertaniannya. Koperasi dapat memudahkan warga menjual hasil pertaniannya ke dalam supermarket. Tujuan lainnya adalah untuk mengedukasi warga agar hasil pertaniannya dilakukan pengkelasan. Misalnya hasil panen caisim dikelaskan menjadi kelas A, B, dan C yang bertujuan agar setiap kelas beda tempat penjualannya. Kelas A warga dapat menjualnya di supermarket, kelas B warga dapat menjualnya di pasar, dan kelas $C$ warga dapat mengolahnya menjadi kripik caisim atau produk lainnya sehingga warga Cibitung Tengah mendapat nilai tambah dan hasil pertanian menjadi optimal. Pembagian kelas ini bisa dari panjangnya caisim yang dihasilkan. Pembuatan brand juga membantu warga untuk membuat brand sendiri agar masyarakat luas lebih mengenal produk khas dari desa Cibitung Tengah. Ini sekaligus dapat menaikan harga jual produk (Tabel 4).

\section{Kendala yang Dihadapi}

Kendala yang dihadapi selama melakukan kegiatan ini adalah tingkat kepedulian masyarakat yang kurang terhadap lingkungan terutama sampah. Penanganan sampah utama masih mengikuti cara tradisional turun-menurun, yaitu dikubur atau dibakar di ladang. Hal tersebut merusak lingkungan karena mengkontaminasi air tanah dan mengganggu keseimbangan mikroba tanah. Selain itu, seiring dengan meningkatnya jumlah penduduk menyingkirkan sampah di ladang tidak dapat dilakukan sehingga sebagian masyarakat mulai membuang sampah di sungai.

Hal tersebut membuat pelaksanaan program tidak bisa langsung terlaksana, perlu penanaman nilai kepedulian terhadap lingkungan terlebih dahulu. Peningkatan kepedulian dilakukan secara bertahap melalui media diskusi, penyuluhan, pelatihan, dan studi banding. Kegiatankegiatan tersebut sebagian besar dilakukan secara non formal mengikuti ritme hidup 
Tabel 3 Harga sampah di bank sampah

\begin{tabular}{|c|c|c|c|c|c|c|c|}
\hline \multirow[t]{2}{*}{ Jenis plastik } & \multirow[t]{2}{*}{ Kode } & \multicolumn{2}{|c|}{$\begin{array}{l}\text { Harga anggota } \\
\text { kelompok (Rp) }\end{array}$} & \multicolumn{2}{|c|}{ Harga BSM (Rp) } & \multicolumn{2}{|c|}{$\begin{array}{c}\text { Keuntungan kelompok } \\
\text { binaan (Rp) }\end{array}$} \\
\hline & & Langsung & Ditabung & Langsung & Ditabung & Langsung & Ditabung \\
\hline PP Bening (toko) & P1 & 2200 & 2400 & 2400 & 2600 & 200 & 200 \\
\hline PP Bening Kotor & $\mathrm{P} 2$ & 1100 & 1300 & 1300 & 1500 & 200 & 200 \\
\hline PP Sablon & P3 & 300 & 400 & 400 & 500 & 100 & 100 \\
\hline PP Blok (Bungkus Mie Instan) & $\mathrm{P} 4$ & 200 & 300 & 300 & 400 & 100 & 100 \\
\hline Kresek/sunlight kecil & P5 & 200 & 300 & 300 & 400 & 100 & 100 \\
\hline PE Bersih & P6 & 1050 & 1050 & 1150 & 1250 & 100 & 100 \\
\hline PE Kotor & P7 & 550 & 650 & 6500 & 750 & 100 & 100 \\
\hline Plastik sunlight besar & P8 & 400 & 500 & 500 & 600 & 100 & 100 \\
\hline PE Slopan (bimoli) & P9 & 450 & 525 & 525 & 600 & 75 & 75 \\
\hline PP aqua gelas bersih & P10 & 5500 & 6000 & 6000 & 6500 & 500 & 500 \\
\hline PP aqua gelas kotor & P11 & 4300 & 4500 & 4500 & 4700 & 200 & 200 \\
\hline Gelas ale ale & $\mathrm{P} 12$ & 2100 & 2300 & 2300 & 2500 & 200 & 200 \\
\hline PET botol bening bersih & P13 & 4400 & 4700 & 4700 & 5000 & 300 & 300 \\
\hline PET botol bening kotor & P14 & 3600 & 3800 & 3800 & 4000 & 200 & 200 \\
\hline PET botol warna bersih & P15 & 2600 & 2800 & 2800 & 3000 & 200 & 200 \\
\hline PET botol warna kotor & P16 & 2100 & 2300 & 2300 & 2500 & 200 & 200 \\
\hline PP bak warna & P17 & 2400 & 2600 & 2600 & 2800 & 200 & 200 \\
\hline PP bak hitam & P18 & 1200 & 1350 & 1350 & 1500 & 200 & 150 \\
\hline HDPE blowing & P19 & 2400 & 2600 & 2600 & 2800 & 200 & 200 \\
\hline Jurigen & P20 & 360 & 3800 & 3800 & 4000 & 200 & 200 \\
\hline Kulit kabel & P21 & 800 & 1000 & 1000 & 1200 & 200 & 200 \\
\hline Paralon & $\mathrm{P} 22$ & 700 & 800 & 800 & 900 & 100 & 100 \\
\hline LDPE infus & P23 & 4100 & 4300 & 4300 & 4500 & 200 & 200 \\
\hline $\begin{array}{l}\text { Karpet/talang plastik/jas } \\
\text { hujan }\end{array}$ & $\mathrm{P} 24$ & 550 & 625 & 625 & 700 & 75 & 75 \\
\hline Tutup aqua botol & P25 & 2100 & 2350 & 2350 & 2600 & 250 & 250 \\
\hline Tutup botol warna & P26 & 2100 & 2350 & 2350 & 2600 & 250 & 250 \\
\hline Tali PET & P27 & 600 & 700 & 700 & 800 & 100 & 100 \\
\hline Selang Air & P28 & 950 & 1100 & 1100 & 1250 & 150 & 150 \\
\hline Giangsi utuh 50 Kg/biji & P29 & 250 & 325 & 325 & 400 & 75 & 75 \\
\hline Giangsi utuh $25 \mathrm{Kg} / \mathrm{biji}$ & P30 & 150 & 225 & 225 & 300 & 75 & 75 \\
\hline Giangsi utuh $10 \mathrm{Kg} / \mathrm{biji}$ & P31 & 100 & 175 & 175 & 250 & 75 & 75 \\
\hline Glangsi rusak & P32 & 250 & 325 & 325 & 400 & 75 & 75 \\
\hline Plastik keras & P33 & 550 & 650 & 650 & 750 & 100 & 100 \\
\hline Plastik keras bening & P34 & 2450 & 2600 & 2600 & 2750 & 150 & 150 \\
\hline CD/DVD/MP3/Kaset PS & P35 & 2600 & 2800 & 2800 & 3000 & 200 & 200 \\
\hline Galon PC rusak & P36 & 3100 & 300 & 300 & 3500 & 200 & 200 \\
\hline Aki kecil & AK37 & 6000 & 7000 & 7000 & 8000 & 1000 & 1000 \\
\hline Aki keciAki besar tanggung & AK38 & 13000 & 14000 & 14000 & 15000 & 1000 & 1000 \\
\hline Aki besar Mobil 50 jet & AK39 & 18000 & 19000 & 19000 & 20000 & 1000 & 1000 \\
\hline
\end{tabular}

masyakat agar lebih mengena, misalnya diskusi dalam bentuk ngariung pada sore hari selepas sholat ashar dan penyuluhan di balai desa dengan nara sumber dosen atau praktisi.

Kendala lain terkait sistem kelembagaan adalah minimnya pengetahuan masyarakat mengenai sistem kerja koperasi. Hal ini membuat proses keuangan dan kelembagaan bank sampah terhambat. Selain itu, branding produk desa menjadi sulit dilakukan karena tidak memiliki suatu wadah legal formal.

\section{Analisis SWOT Pengelolaan} Pengembangan Desa Cibitung Tengah

dan

Berdasarkan analisis potensi, hasil wawancara dengan stakeholder, dan tokoh masyarakat, serta hasil observasi lapang faktor internal (kekuatan dan kelemahan) dan faktor eksternal (peluang dan ancaman), diidentifikasi untuk mendapatkan analisis pengelolaan dan strategi pengembangan Desa Cibitung Tengah sebagai desa ketahanan pangan dan desa nirlimbah (Rangkuti 2006).

Analisis faktor internal menunjukkan bahwa faktor internal yang menjadi kekuatan (strength) antara lain: 1) Memiliki sumber daya alam yang melimpah terutama di bidang pertanian; 2) Tingginya potensi di sektor pertanian, peternakan, dan perikanan; 3) Tingginya limbah organik yang dapat dimanfaatkan menjadi pupuk; 4) Sudah ada kelembagaan petani seperti Gapoktan; dan 5) Memiliki lahan yang subur dengan pemandangan yang indah. 


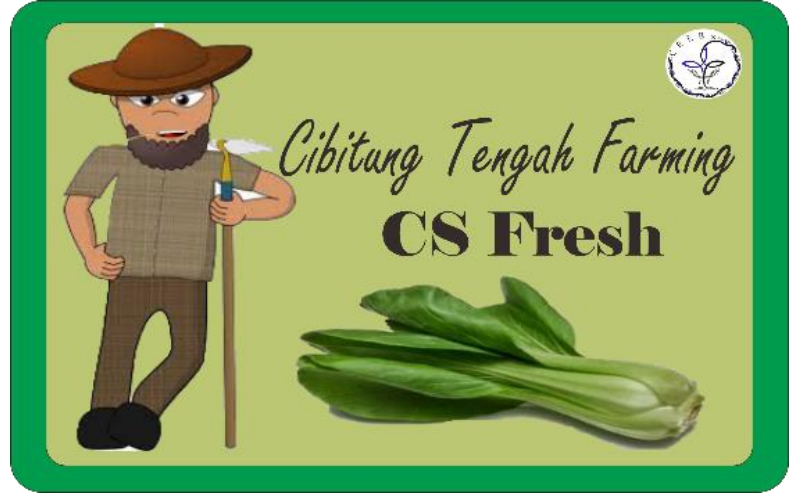

Gambar 4 Brand produk pertanian Cibitung Tengah.

Tabel 4 Produk CS Fresh

\begin{tabular}{|c|c|}
\hline $\begin{array}{c}\text { Produk sebelum } \\
\text { diolah }\end{array}$ & Produk sesudah diolah \\
\hline $\begin{array}{l}\text { Caisim segar: Rp } \\
500-5000 / \mathrm{kg}\end{array}$ & $\begin{array}{l}\text { Kripik caisim Rp 8000/ons } \\
\text { Caisim yang di packing Rp } \\
4000 / 2 \text { ons } \\
\text { Pakan dari maggot kering Rp } \\
25.000 / 150 \mathrm{~g} \\
\text { Pakan dari maggot Basah Rp } \\
5.000 / \mathrm{kg}\end{array}$ \\
\hline
\end{tabular}

Faktor internal yang menjadi kelemahan (weakness) adalah: 1) Banyaknya sampah organik dari limbah ladang, kandang, dan dapur maupun sampah non-organik; 2) Masyarakat kurang peduli terhadap lingkungan terutama kepedulian tentang sampah; 3) Kurangnya sarana dan prasarana untuk pembuangan dan pengolahan sampah; 4) Lemahnya kelembagaan dan organisasi berbasis masyarakat; 5) Pemanfaatan iptek masih rendah; 6) Belum ada pengolahan limbah organik dan non-organik; 7) Belum adanya kemitraan teknologi; 8) Kebiasaan berkoperasi rendah; dan 9) Ibu rumah tangga masih banyak yang menganggur.

Hasil analisis faktor eksternal kawasan menunjukkan bahwa faktor-faktor eksternal yang menjadi peluang (oppurtunity) terciptanya desa ketahanan pangan dan desa nirlimbah adalah: 1) Adanya dukungan dari stakeholder (pemerintah setempat) dan tokoh masyarakat dalam menjalankan program pemberdayaan masyarakat melalui pertanian terpadu; 2) Adanya penyuluhan-penyuluhan pertanian dari pemerintah; 3) Adanya penyuluhan tentang pengolahan sampah dan teknologi pengolahan sampah dari mahasiswa IPB; 4) Pemanfaatan limbah organik dari ladang, kandang, dan dapur menjadi pakan ternak serta pupuk kompos; 5) Menjalin kerja sama dengan mitra perusahaan swasta untuk mewujudkan desa nirlimbah dan ketahanan pangan; 6) Peluang untuk mening- katkan potensi desa seperti membuat produk dari hasil pertanian dan membuat desa wisata; 7) Peluang dibentuknya bank sampah untuk mengolah dan memanfaatkan sampah nonorganiknya; dan 8) Peluang masyarakat membuat produk dari hasil pertanian seperti kripik.

Hasil analisis faktor eksternal yang menjadi ancaman (threat) dalam program pemberdayaan ini adalah: 1) Tidak adanya daerah pemasaran caisim sebagai hasil pertanian komoditas utama masyarakat Cibitung Tengah; 2) Generasi muda banyak yang merantau; 3) Mahalnya harga pakan ternak dan ikan; dan 4) Adanya tengkulak. Berdasarkan analisis faktor internal dan faktor eksternal dapat dibuat matrik SWOT seperti pada Tabel 5.

Berdasarkan matriks SWOT tersebut maka pengembangan Desa Cibitung Tengah sebagai desa ketahanan pangan dan desa nirlimbah dapat dilakukan dengan cara: 1)Memberikan pengetahuan kepada masyarakat melalui pelatihan mengenai perencanaan, pengelolaan serta pemasaran produk baru hasil pertanian; 2) Memberikan pengetahuan kepada masyarakat mengenai pengelolaan, dampak, teknologi dan pemanfaatan limbah ladang, kandang, dan dapur; 3) Membuat sistem bank sampah untuk pengelolaan dan pemanfaatan sampah non-organik; 4) Pembangunan infrastruktur tempat pembuangan sampah sementara dan teknologi pengolahan sampah; 5) Membuat koperasi agar membuka pemasaran produk hasil pertanian; dan 6) Mengaplikasikan teknologi agar meningkatkan nilai ekonomi hasil pertanian dan pemanfaatan sampah.

\section{SIMPULAN}

Program pengelolaan sampah terintegrasi di Desa Cibitung Tengah membantu mendorong warga untuk memecahkan 3 permasalahan utama, yaitu permasalahan sampah sekaligus permasalahan pemakaian pupuk kimia, harga pakan ternak, dan pemasaran produk dari hasil pertanian setempat. Program ini berhasil menghasilkan produk baru atau hasil olahan yang dapat menambah pendapatan masyarakat setempat seperti hasil pengolahan maggot, produk CS-Fresh, hasil dari bank sampah, dan hasil kerajinan dari sampah.

Usulan terkait keberlanjutan program pemberdayaan ini selamjutnya adalah buku manual pengelolaan limbah organik dan pengelolaan bank sampah, serta pupuk organik 
Tabel 5 Matriks analisis SWOT

\begin{tabular}{|c|c|c|}
\hline & Kekuatan/strength $(\mathrm{S})$ & Kelemahan /weakness (W) \\
\hline $\begin{array}{l}\text { Faktor } \\
\text { eksternal }\end{array}$ & Strategi SO & Strategi WO \\
\hline \multirow[t]{2}{*}{$\begin{array}{l}\text { Peluang/ } \\
\text { oppurtunities } \\
\text { (0) }\end{array}$} & $\begin{array}{l}\text { 1. Meningkatkan dan mengoptimalkan } \\
\text { hasil produksi pertanian } \\
\text { 2. Membagi grade pada hasil pertanian } \\
\text { agar lebih banyak yang dapat } \\
\text { dimanfaatkan dan lebih banyak } \\
\text { keuntungan yang didapat } \\
\text { 3. Mengembangkan teknologi yang } \\
\text { dapat memanfaatkan limbah kandang, } \\
\text { ladang dan dapur untuk dijadikan } \\
\text { pakan ternak dan pupuk kompos } \\
\text { 4. Peningkatan pengetahuan } \\
\text { masyarakat melalui penyuluhan } \\
\text { pertanian dan sampah sehingga } \\
\text { masyarakat dapat mengoptimalkan } \\
\text { hasil pertaniannya dan dapat } \\
\text { mengolah serta memanfaatkan } \\
\text { sampah yang ada di desa Cibitung } \\
\text { Tengah. } \\
\text { 5. mengembangkan produk hasil } \\
\text { pertanian agar meningkatkan nilai } \\
\text { jual hasil pertanian. } \\
\text { 6. Membuat sistem bank sampah agar } \\
\text { membantu mengurangi sampah dan } \\
\text { menambah pendapatan masyarakat. }\end{array}$ & $\begin{array}{l}\text { 1. Meningkatkan pengolahan sampah organik } \\
\text { menjadi pupuk dan pakan ternak dan } \\
\text { sampah non organik menjadi kerajinan. } \\
\text { 2. Meningkatkan SDM melalui penyuluhan dan } \\
\text { pelatihan terutama di bidang pertanian dan } \\
\text { pengetahuan tentang sampah serta } \\
\text { pengolahannya } \\
\text { 3. Menyosialisasikan kepada masyarakat } \\
\text { tentang pentingnya pengolahan sampah agar } \\
\text { meningkatkan rasa kepeduliannya. } \\
\text { 4. Menjalin hubungan antara mitra perusahaan } \\
\text { swasta untuk meningkatkan teknologi yang } \\
\text { dapat membantu warga Cibitung Tengah. } \\
\text { 5. Membangun tempat pembuangan sampah } \\
\text { sementara beserta tempat pengolahannya. } \\
\text { 6. Meningkatkan lembaga sosial masyarakat } \\
\text { dengan mengikutsertakan masyarakat dalam } \\
\text { acara-acara negeri dan menampung aspirasi } \\
\text { masyarakat. } \\
\text { 7. Meningkatkan pemanfaatan IPTEK melalui } \\
\text { pendidikan gratis dari pemerintah } \\
\text { 8. Membentuk koperasi untuk menghindari } \\
\text { tengkulak. }\end{array}$ \\
\hline & Strategi ST & Strategi WT \\
\hline $\begin{array}{l}\text { Ancaman/ } \\
\text { threat (T) }\end{array}$ & $\begin{array}{l}\text { 1. Mencari daerah pemasaran hasil } \\
\text { pertanian Desa Cibitung Tengah } \\
\text { terutama caisim seperti ke } \\
\text { supermarket atau warung-warung } \\
\text { mie ayam. } \\
\text { 2. Meningkatkan sarana dan prasarana } \\
\text { melalui kerjasama antar pemerintah } \\
\text { maupun mitra perusahaan swasta. } \\
\text { 3. Mengembangkan produk baru dari } \\
\text { hasil pertanian agar nilai ekonominya } \\
\text { meningkat } \\
\text { 4. Mengembangkan teknologi-teknologi } \\
\text { pengolahan sampah organik dan non } \\
\text { organik agar meningkatkan nilai } \\
\text { ekonomi dari hasil pengolahan } \\
\text { tersebut. }\end{array}$ & $\begin{array}{l}\text { 1. Membuat sistem koperasi agar membuka } \\
\text { pemasaran hasil pertanian } \\
\text { 2. Meningkatkan SDM agar mandiri dalam } \\
\text { menginovasi pengolahan sampah dan } \\
\text { pertanian. }\end{array}$ \\
\hline
\end{tabular}

sistem BSF dan pakan ternak (Maggot BSF) dalam kemasan, dan pembentukan koperasi berakta notaris sebagai wadah gerakan, yang dikelola oleh Gapoktan dan KWT. Program ini akan terus berlanjut sampai masyarakat Cibitung Tengah mandiri dan dapat mewujudkan desa ketahanan pangan serta desa nirlimbah.

\section{UCAPAN TERIMA KASIH}

Terima kasih kepada Kementerian Riset dan Teknologi Perguruan Tinggi dalam mendanai program pengolahan sampah terintegrasi Desa Cibitung Tengah dalam Program Hibah Bina Desa. Terimakasih juga disampaikan kepada para 
mitra, yaitu PT Biomagg Indonesia, Koper, Rangga Mekar, dan pemerintah daerah yang telah mendukung program ini.

\section{DAFTAR PUSTAKA}

Dian PR, Ira R. 2016. Analisis Pengelolaan Desa Pajambon Kecamatan Karyamulya Kabupaten Kuningan Sebagai Desa Ekowisata. Proceeding Biology Education Conference. 13(1): 683689.

Diener S, Zurbrügg C, Guiterrez FR, Nguyen DH, Morel A, Koottatep T, Tockner K. 2011. Black Soldier Fly Larvae For Organic Waste Treatment-Prospects And Constraints. In: Proceedings of the WasteSafe 2011-2nd International Conference on Solid Waste Management in the Developing Countries. Khulna, Bangladesh, 13-15th February 2011.

Elsa. 2012. Strategi pengembangan desa tertinggal di Nagari Batu Banyak Kecamatan Lembang Jaya Kabupaten Solok. Jurnal Spasial. 1(1): $\quad 52-73 . \quad$ https://doi.org/10. 22202/js.v1i1.1573

Harrison JH, Blauwiekel R, Stokes MR. 1994.
Fermentation and untilization of grass silage. Journal of Dairy Science. 77(10): 3209-3235. https://doi.org/10.3168/jds.S00220302(94)77264-7

Inrianti, Tuhuteru S, Paling S. 2019. Pembuatan mikroorganisme lokal bonggol pisang pada Kelompok Tani Tunas Harapan Distrik Walelagama, Jayawijaya, Papua. Agrokreatif Jurnal Ilmiah Pengabdian kepada Masyarakat. 5(3): 188-194. https://doi.org/ 10.29244/agrokreatif.5.3.188-194

Paz ASP, Carrejo NS, Rodriguez CHG. 2015. Effects of larval density and feeding rates on the bioconversion of vegetable waste using Black Soldier Fly larvae Hermetia illucens (L.). Waste and Biomass Valorization. 6: 1059-1065. https://doi.org/10.1007/s12649-015-94188

Rangkuti F. 2006. Analisis SWOT Teknik Membedah Kasus Bisnis. Jakarta (ID): PT. Gramedia Pustaka Utama.

Wardhana AH. 2016. Black Soldier Fly (Hermatia illucens) sebagai sumber protein alternatif untuk pakan ternak. Wartazoa. 26(2): 69-78. https://doi.org/10.14334/wartazoa.v26i2.13 27 